\title{
Konceptualna metafora i problemi prevođenja (na primjeru koncepta LJUBAV u romanu Čevengur A. Platonova)
}

\section{Abstract: Conceptual Metaphor and Translation Problems (metaphors for LOVE in Andrei Platonov's Chevengur)}

The aim of this paper is to research the translation procedures of metaphors for LOVE in the novel Chevengur by Andrei Platonov by using a corpus linguistics search tool to explore the potential of corpus analysis in literary translation. The research shows that the analyzed translation is dominated by the M M procedure, that is, translation with the same conceptual metaphor and, more precisely, with the same linguistic expression. A few exceptions can be explained by different conventions of the Croatian language and the Russian, while, certainly, particular translator's motivations remain beyond the scope of the research. The observed dominance of the said procedure does not surprise if one takes into account the possibilities of the source and target languages - the Slavic cultural and linguistic heritage which, at least to some extent, enables the understanding of shared concepts and the usage of the same linguistic expressions. The research also proves the potential of corpus analysis in certain cases when dictionary/-ies reach their limit as a control corpus and when the translator's intuition fails to solve the issues of nuanced deviations from the conventional usage of metaphoric expressions.

Keywords: literary translation, conceptual metaphor, corpus search, Chevengur, Andrei Platonov

\section{Uvod}


Prevođenje književno-umjetničkih tekstova i danas se vrlo malo oslanja na znanstvene alate i još je uvijek prilično „klasična” aktivnost koja uključuje usamljenu, eruditsku osobu prevoditelja okruženu knjigama kao najkvalitetnijim alatom koji mu/joj može pomoći pri prevođenju.

Ipak, sa sve većim razvojem različitih lingvističkih alata, korpusa, neuronskih mreža i sl. postavlja se pitanje na koje se sve načine ovi alati mogu koristiti u prevođenju književno-umjetničkih tekstova. To su alati koji svakodnevno dokazuju svoju vrijednost u prevođenju stručnih tekstova, ali velika raznovrsnost i kreativnost književno-umjetničkih tekstova s pravom postavlja pitanje mogu li se uopće (i kako) ovi programi i alati izboriti s raznovrsnošću i inovacijama u jeziku koje karakteriziraju takve tekstove.

Čak i kod prevoditelja koji iznimno dobro poznaju jezik s kojeg prevode mogu se pronaći situacije u kojima nije siguran koliko je neka formulacija uobičajena i stilski neutralna. U tom smislu korpusi mogu biti vrlo korisni jer jasno navode primjere i mogu dati prevoditelju odličnu referencu o upotrebljivosti pojedinih izraza. Specifičan pothvat može predstavljati prevođenje konceptualnih metafora. Bilo da govorimo o onima visoke konvencionalnosti i frekventnosti koje gotovo nevidljivo vežu naizgled nepovezane leksičke jedinice u koherentne strukture sa svojim osobitim asocijativnim nizom koji se ne mora u dva jezika podudarati ili pak o inovativnim autorskim metaforama - kreativnim pomicanjima relativno ustaljenih kulturnih i jezičnih granica. Već je i samo prepoznavanje metafora, ali i važnosti razlike među njima, zahtjevan korak, kojemu slijedi odluka o tome kako in adekvatno prenijeti.

Kao što navodi Christina Schäffner, problemi prevođenja metafora predmet su brojnih istraživanja unutar teorije prevođenja (1254) te su prepoznati kao problem s obzirom da prenošenje metafora iz jednog jezika i kulture u drugi može biti pod utjecajem jezičnih i kulturnih razlika. No tek je relativno nedavno u teoriji prevođenja primijenjen kognitivni pristup; kao što ističe Schäffner, kognitivni pristup metafori (naravno, iniciran poglavito nezaobilaznom knjigom Lakoffa i Johnsona Metaphors We Live By) može dati nove uvide u prevođenje (1254). lako su mnoga istraživanja zaključila da nisu sve metafore specifične za samo jedan jezik i da mogu biti iste u različitim jezicima i kulturama, postoje mnoge metafore koje su snažno uvjetovane pojedinim kulturama, kako ističe Dobrzynska (597). 
Ponekad je problem jednostavno „riješiti” na način da se pribjegne nultom prijevodu, tj. da se izbjegne prijevod u ciljnom jeziku, ali to nije uvijek moguće jer neke metafore mogu imati veliki značaj u pojedinim tekstovima (Božić, „On translating metaphors” 88). Inovativne autorske i konvencionalne konceptualne metafore mogu se razlikovati u mnogome, ali u prevoditeljskom smislu vrlo često prevoditelj mora „izabrati” jednu „pravu” interpretaciju metafore. Astrid Jensen podsjeća da ukoliko prevoditelj izabere krivu interpretaciju, cijeli tekst na ciljnom jeziku može dobiti drugo značenje (189). Ne govorimo ovdje o tome da u prijevodu tekstovi nemaju onu višeznačnost koja se susreće u njihovu izvorniku. To je, naravno, obično tako i ta identičnost višeznačnosti zapravo se i ne očekuje od prijevoda, ali iako poruka nije jednako „bogata”, ipak prevoditelj nastoji očuvati najvažnije razine značenja i tekst je u svojoj osnovi ipak ista poruka (Božić, „On translating metaphors” 89). Metafore se nikako ne smiju promatrati samo kao „ukrasi teksta”, one to svakako nisu, već, kako se ističe u kognitivnom pristupu metafori, metafore dodaju semantičku kvalitetu tekstu (Božić, „On translating metaphors” 88).

Kao što ističe Ušakova, lingvističke i semantičke karakteristike elemenata metafora zavise i o nacionalnosti prevoditelja, odnosno o kulturnoj i jezičnoj podlozi prevoditelja (86). Tako se isti koncepti mogu različito prevoditi (Ušakova 86).

Potrebno je provoditi istraživanja o mogućnostima različitih alata kako bi se što više smanjio utjecaj prevoditeljeve „intuicije”. lako je „intuicija” zapravo skup znanja koja je prevoditelj stekao svojim cjeloživotnim radom i učenjem, s obzirom na to da se ipak temelji „samo” na subjektivnim mogućnostima prevoditelja, ona ponekad može predstavljati značajan problem te je potrebno osigurati prevoditeljima što dostupnije „objektivne” alate koji im mogu pomoći upravo u ovoj iznimno teškoj razini jezika.

\section{Cilj i metode istraživanja}

Cilj je ovoga rada istražiti postupke prijevoda metafora LJUBAVI u romanu Čevengur Andreja Platonova pomoću korpusnog alata za pretraživanje teksta u 2005. godine objavljenom prijevodu. Ujedno istražujemo u kojoj je mjeri moguće upotrijebiti jedan od lingvističkih alata kao pomoć pri prevođenju metafora shvaćenih u okvirima kognitivnolingvističke teorije. Ovaj su tekst i njegov 
prijevod izabrani upravo zbog specifične i često „agramatične” poetike Platonova, koja i dobre poznavatelje ruskoga jezika, ali ne izvorne govornike, često ostavlja u nedoumici.

Metafori se pristupa primarno na jezičnoj razini kao produktu koji je moguće analizirati, ali je se shvaća u okvirima suvremene teorije konceptualne metafore, prema kojoj metafora nije tek retoričko pitanje, nego pojava neraskidivo povezana s čovjekovim mišljenjem. Metafora je teorijski definirana kao preslikavanje među različitim konceptualnim domenama, odnosno indirektna konceptualizacija, a u lingvističkoj je analizi prepoznajemo kao pojavu inkongruentnosti na razini diskursa, bilo da se ona očituje kroz direktan ili indirektan jezik, koja zahtijeva razrješavanje uvođenjem druge, pretpostavljene izvorne konceptualne domene na temelju nekog oblika sličnosti, primjenjujući time MIPVU metodu određivanja jezičnih metafora (Steen et al. 11-12). Uzimajući u obzir čovjekovu kognitivnu sposobnost metaforizacije i manifestiranje konceptualnih metafora u jeziku, prijevodu pristupamo iz dvojne perspektive, istražujući postupke prijevoda jezičnih izraza i konceptualnih metafora u kojima su utemeljeni, pri čemu se zaključci o potonjem izvode na temelju tekstualnih podataka i dostupnih prethodnih istraživanja.

Kako bi se dobio uvid u izvornu uporabu metafora, odnosno uporabu u originalnom tekstu, prvi je korak istraživanja bio pretraga lema любовь „ljubav” і любить „voljeti” и izvornoj verziji romana Čevengur, a pretraga teksta vršila se pomoću korpusnih alata dostupnih u referentnom korpusu Национальный корпус русского языка, u sklopu kojega je dostupan i sam roman. Kao kontrolni korpus korišten je i jedan od najkvalitetnijih rusko-ruskih rječnika Толковый словарь Ожегова, dostupan u elektroničkoj verziji te Hrvatski jezični portal za hrvatski jezik. Uzorci uporabe metafora na razini originalnog teksta analizirani su u okviru teorije Elene Semino u Metaphor in Discourse. Drugi se korak sastojao od potrage za dijelovima prijevoda koji odgovaraju pronađenim uporabama u izvorniku[1] Pri analizi prijevoda metafora vodimo se tipologijom postupaka prevođenja metafora koju zagovara Goran Schmidt u Konceptualne metafore u prevođenju. Kombinacijom elemenata traduktološke tipologije Gideona Touryja i kognitivnolingvističkog pristupa Zoltana Kövecsesa Schimdt dolazi do šest kategorija, tj. osam mogućih prevoditeljskih postupaka. Konceptualna se metafora može prevesti: 1. istom konceptualnom metaforom (M M) putem tri postupka: a) prevođenjem istim jezičnim izrazom, b) različitim jezičnim izrazom iste konceptualne metafore ili c) pomoću poredbe; 2. različitom konceptualnom metaforom (M M1); 3. nemetaforičkom parafrazom 
(M ne-M); 4. ispuštanjem metafore (M Ø); te se konceptualna metafora u prijevodu može uvesti 5. ondje gdje je izvorniku stajala nemetafora (ne-M M); i 6. gdje ničega nije bilo (Ø M) (124-125).

\section{Analiza}

Korpusna pretraga leme любовь „ljubav” rezultirala je s 42 pojavnice. Analizom konteksta na razini rečenice s pojavnicom pronašli smo 27 metaforičkih uporaba - jedinica koje pokazuju metaforičku uporabu u odnosu na jedinicu любовь, odnosno koje u tekst uvode druge izvorne domene uspostavljajući istovremeno vezu s ciljnom domenom LJUBAV.

Kao što je bilo očekivano, razmjerno velik broj slučajeva, njih 9, otpada na prepozicijske odnose s prijedlozima čije je temeljno značenje prostorno determinirano. Visok udio odraz je produktivnosti prostornih prijedloga u ekstenzijama značenja i prijenosima na ne-prostorne, nerijetko apstraktne domene. Kao odrazi temeljnih metaforičkih tendencija konceptualizacija apstraktnih koncepata, takve su uporabe konvencionalne za jezik i stilski sasvim neobilježene; njihovo je značenje visoko shematično, što znači da koncept LJUBAV ne ispunjavaju nikakvim specifičnim značenjem, nego mu samo pridaju konkretnije obrise i ustrojavaju uzročne-posljedične odnose drugih jedinica s njime. U pet primjera prepozicije čije je temeljno značenje prostorno u ruskom jeziku, i stoga in smatramo metaforičnima u kontekstu, prevedene su nemetaforama čija značenja odgovaraju metaforičkim značenjima prostornih prepozicija.

1) Он наполнялся тем темным воодушевленным волнением, какое бывает у взрослых людей при единственной любви к женщине.

Punio se onom tamnom oduševljenom brigom kakva biva kod odraslih ljudi kada vole jednu ženu. (Platonov 50)

$\mathrm{DP}^{[2]}$ pri

2) Лесной надзиратель, хранивший леса из любви к науке, в этот час сидел над старинными книгами.

Šumski nadzornik koji je čuvao šume zbog ljubavi prema znanosti toga je trenutka sjedio za starim knjigama. (Platonov 127) 
DP: iz

3) Над пустынной бесприютностью степи всходило вчерашнее утомленное солнце, и свет его был пуст, словно над чужой забвенной страной, где нет никого, кроме брошенных людей на кургане, жмущихся друг к другу не от любви и родственности, а из-за недостатка одежды. Nad pustom, negostoljubivom stepom bez utočišta, izlazilo je jučerašnje umorno Sunce i njegova svjetlost bijaše prazna, baš kao iznad tuđe zaboravljene države u kojoj nikoga nema osim ljudi bačenih na humak, ljudi koji su se primicali jedni drugima, ne zbog ljubavi i krvnog srodstva, nego zbog nedostatka odjeće. (Platonov 277)

DP: od

4) Из-за любви ко двору я тебя, как буржуя, выгнал помирать, а теперь я хочу здесь привыкнуть жить, хочу устроить для бедных, как для родных, и самому среди них успокоится, - и никак не могу...

Zbog te ljubavi sam tebe, kao buržuja, otjerao da umreš, a sada se želim ovdje naviknuti živjeti, želim graditi za siromašne, kao za rođene, i među njima se smiriti - a nikako ne mogu... (Platonov 327)

DP: $i z^{[3]}$

5) Потому что природу мы уважаем за еду, а женщин за любовь.

Zato što prirodu poštujemo radi hrane, a žene radi ljubavi $i^{[4]}$ (Platonov 383)

DP: za

U sljedeća se četiri primjera prepozicije prevode prepozicijama koje i u hrvatskom jeziku imaju temeljno prostorno značenje. Prijevodi pod 7, 8 i 9 primjeri su postupka M M istim jezičnim izrazom, dok primjer 6 svrstavamo pod prevođenje različitim jezičnim izrazom iste konceptualne metafore, odnosno onoga što ovdje uopćavamo kao konceptualizaciju uzročnih odnosa na temelju prostornih odnosa.

6) Пролетариат ведь тоже родился не от любви, а от факта.

I proletarijat se nije rodio iz ljubavi, nego kao činjenica. (Platonov 241) 
DP: od

7) ... утомление и есть единственное утешение в любви.

... umor i jest jedina utjeha u ljubavi. (Platonov 357)

8) Позднее, когда стихали улицы и спали друзья и любовники, Сербинов успокаивался: в этот час уже многие были одинокими - кто спал, кто утомился от беседы или любви и лежал один, - и Сербинов тоже соглашался быть одним.

Kasnije, kad su utihnule ulice i prijatelji i ljubavnici spavali, Serbinov bi se umirio: tada su već mnogi bili usamljeni - netko je spavao, netko se umorio od razgovora ili ljubavi i ležao sam - i Serbinov se slagao biti sam. (Platonov 359)

9) Прокофий их пробовал во время путешествия сжимать, забирая в фраэтон для испытания, но они кричали от его любви, как от своей болезни.

Prokofij in je probao stezati za vrijeme puta, uzimajući in u kočiju radi probe, ali od njegove ljubavi one su vikale, kao od vlastite bolesti. (Platonov 384)

Sljedećih pet primjera, koje prema metaforama u originalu grupiramo zajedno zbog njihova daljnjeg konkretiziranja ljubavi kao nečega što ima fizičku pojavnost samo po sebi, a ne kroz svoje inače vidljive „simptome”, pokazuju kako se u prijevodu i dalje preferira postupak M M, s time da se u primjerima 12, 13 i 14 prevoditelj služi istim jezičnim izrazom, dok se u primjeru 11 odlučuje za drugi izraz iste konceptualne metafore; iako je riječ увеличивалась moguće prevesti s „u/povećavala se", pretpostavka je da je prevoditeljska odluka vođena konvencionalnošću uporabe glagola rasla s imenicom ljubav u hrvatskom jeziku. Jedino je u primjeru 10 u prijevodu došlo do zamjene nemetaforičkim izrazom.

10) В нем поднялась едкая теплота позора за взрослых, он сразу потерял любовь к ним и почувствовал свое одиночество - ему захотелось убежать и спрятаться в овраг.

U njemu se podigla opora toplina sramote za odrasle, istog trena je nestalo njegove ljubavi prema njima pa je osjetilo svoju samoću - poželjelo je pobjeći i skriti se u jarugu. (Platonov 22-23)

DP: izgubio ljubav

11) Он обнял Сашу и заплакал, его любовь к приемному сыну все время увеличивалась. 
Njegova ljubav prema posvojenom sinu sve više je rasla. (Platonov 171)

12) Корми нас, а потом спать клади: хлеб вместе и любовь пополам.

Nahrani nas, a onda nas stavi u postelju; kruh zajedno i ljubav po pola. (Platonov 350)

13) Но проходило время равнодушного отдыха, и Кирей чувствовал несчастие, бессмысленность жизни без вещества любви...

Ali prolazilo bi vrijeme ravnodušnog odmora i Kirej je osjećao nesreću, besmislenost života bez tvari ljubavi... (Platonov 397)

14) У Дванова не было в запасе никакой неподвижной любви, он жил одним Чевенгуром и боялся его истратить.

Dvanov nije imao u pričuvi nikakvu nepomičnu ljubav, živio je samo za Čevengur i bojao se da ga ne izgubi. (Platonov 399)

Kao što pretraga osnovnog korpusa, koji sadrži 115197 pojavnica leme любовь, pokazuje, primjeri ovakvih uporaba ipak su manje rasprostranjeni u općoj uporabi jezika za razliku od prijedloga, posebice primjeri uporaba 12 і 13. Потерять любовь „izgubiti ljubav” najčešći je slučaj. Već je pretraga jedinice потерять jedno mjesto lijevo od любовь dala 43 rezultata. Pretragu uporaba glagola увеличиваться „uvećavala se” proširili smo na čak deset mjesta, prvo desno, a zatim i lijevo, i dobili tek sedam rezultata. Isto smo učinili i s jedinicom пополам „po pola” i dobili šest rezultata. Očigledno, takva je uporaba rijetka i neuobičajena. Kövecses smatra da je metafora (ROMANTIČNA) LJUBAV JE JEDINSTVO jedan od osnovnih načina konceptualizacije LJUBAVI ( Metaphors of Anger, Pride and Love 62), pri čemu dana metafora „sugerira savršenu harmoniju, idilično stanje" (63). Premda se njegovi zaključci temelje na engleskom jeziku i metafore LJUBAVI u ruskom tek zahtijevaju svoja istraživanja, uzevši u obzir da takva konceptualizacija nije strana u ruskom jeziku, kao što pokazuje postojanje izraza любовь - это единство „ljubav je jedinstvo”, две половинки одного целого „dvije polovice jednog cijelog”, неразлучные „nerazdvojni” itd., spomenuta uporaba metafore пополам „ро pola” sugerira svojevrsno prevrednovanje prepoznate metafore u smjeru suprotnom onom idiličnog stanja, a u suglasju je s materijalnom prirodom ljubavi kod Platonova. Uporabe imenice запас „zaliha” u konstrukcijama s любовь češća je - pretraga je proizvela ukupno 32 rezultata, uključujući desna i lijeva mjesta. Međutim, Platonovljeva 
konstrukcija не было в запасе любви „nije bilo u pričuvi ljubavi” ostaje osobitošću s obzirom na to da u osnovnom korpusu dominira genitivna konstrukcija запас(ы) любви „zaliha/-e ljubavi”. Pretraga uporaba imenice вещество „tvar” nije dala ni jedan rezultat.[5] Vodeći se prijedlogom Alice Deignan da se svako značenje riječi na koje nalazimo manje od jedanput na svakih 1000 citata dane riječi može opisati kao inovativno ili rijetko (40), ovu ćemo metaforu smatrati inovativno platonovskom - zadržavanje specifičnosti takve uporabe čini se stoga važnom i primjerenom odlukom u danom prijevodu.

Osim konkretiziranja koncepta LJUBAV, na jezičnoj razini prepoznajemo i nekoliko uporaba koje bismo mogli svrstati u kategoriju personifikacije, posebnog slučaja metafore pri kojemu se inkongruentnost razrješava kroz odnos sličnosti između ljudskog i ne-ljudskog. U većini takvih slučajeva u tekstu metafora ovisi o glagolu kojim se imenici любовь, najčešće u ulozi subjekta, pripisuje djelatna priroda, pa tako ljubav daje, ide, živi, itd. U prijevodu ponovno prevladava postupak M M istim jezičnim izrazom. Iznimku nalazimo u primjeru 17 u vidu prijevoda različitim jezičnim izrazom, pri čemu se odluka može pripisati konvencionalnosti izraza, odnosno konvencionalnosti samog prijevoda jednog od mnogih značenja ruskog glagola kretanja идти (prototipno „ići” ili „hodati”) s imenicom u 3. licu - značenja „približavati se” ili „pojavljivati se”. Samo se u jednom od šest sljedećih primjera, primjeru 19, u prijevodu koristi nemetaforička parafraza koja odgovora značenju „dogoditi se” glagola выходить temeljnog značenja „izlaziti”.

15) Какая вера-надежда-любовь давала силу их ногам на песчаных дорогах - ни одному подающему милостыню не было известно.

Kakva vjera-nada-ljubav daje snagu njihovim nogama na pjeskovitim putovima - nije znao ni jedan čovjek koji im je udijelio. (Platonov 41)

DP: vjera-nada-ljubav davala

16) Иногда он поглядывал на Соню и еще больше любил Розу Люксембург: у обоих была чернота волос и жалостность в теле; это Копенкин видел, и его любовь шла дальше по дороге воспоминаний.

Ponekad je pogledavao Sonju i još više volio Rosu Luxemburg: obje su imale crnu kosu i jadno tijelo; uočio je to pa je njegova ljubav išla dalje stazom uspomena. (Platonov 99-100) 
17) Все было заранее благоустроено: любовь идет в виде фракта...

Sve je bilo ranije uređeno: ljubav dolazi u obliku činjenice... (Platonov 357)

DP: ljubav ide

18) Может быть, это жила в нем отвлеченная любовь молодости, превратившаяся в часть тела, либо продолжающаяся сила рождения.

Možda je to u njemu živjela apstraktna ljubav mladosti koja se pretvarala u dio tijela ili snaga rođenja što je trajala i dalje. (Platonov 151)

19) Без этого как-то вся любовь не выходит...

Bez toga, nekako, i nema ljubavi... (Platonov 359)

DP: ljubav ne izlazi

20) У Дванова не было в запасе никакой неподвижной любви, он жил одним Чевенгуром и боялся его истратить.

Dvanov nije imao u pričuvi nikakvu nepomičnu ljubav, živio je samo za Čevengur i bojao se da ga ne izgubi. (Platonov 399)

21) Не одна любовь к срубленной Розе существовала в сердце Копенкина - она лишь лежала в своем теплом гнезде, но это гнездо было свито из зелени забот о советских гражданах, трудной жалости ко всем обветшалым от нищеты и яростных подвигов против ежеминутно встречающихся врагов бедных.

U njegovom srcu nije postojala samo ljubav prema pogubljenoj Rosi - ona je samo ležala u svom toplom gnijezdu, ali to je gnijezdo bilo savijeno od zelenila brige prema sovjetskim građanima, naporne tuge prema svim onemoćalim od bijede i hrabrih podviga protiv neprijatelja sirotinje koji su stalno nadolazili. (Platonov 130)

Nužno je ipak imati u vidu da se temeljna značenja jedinica koje pripadaju izvornoj domeni metafora LJUBAVI u navedenim primjerima vežu uz živa bića uopće, a ne isključivo ljude; predložena kategorizacija uporaba kao primjera personifikacije relativno je gruba generalizacija u tome smislu. Jedini glagol koji nije dio metafore LJUBAV JE ŽIVO BIĆE nalazimo u primjeru: 
22) Моя любовь теперь сверкает на сабле и в винтовке, но не в бедном сердце!

Moja ljubav sada sja na sablji i pušci, a ne u jadnom srcu! (Platonov 100)

Budući da je temeljno značenje glagola сверкать „sjajiti” ili „svijetliti”, ova uporaba potencijalno ima pozadinu u već istraživanoj konceptualnoj metafori LJUBAV JE VATRA (Kövecses, Metaphors of Anger, Pride and Love 84), prepoznatoj kao konvencionalnoj u engleskom jeziku (Metaphor 324), ali i u srodnijem - hrvatskom (Stanojević 92), odnosno ovisi o izvornoj domeni VATRE, koja je ključna za razumijevanje raznih emocija (Kövecses, „The Scope of Metaphor” 84). Međutim, kao jedini jezični primjer u našoj analizi, teško ga je kategorički pripisati navedenoj konceptualnoj metafori; ljubav je tek opisana kao nešto što sjaji. U svakom slučaju, u prijevodu opet nalazimo postupak M M istim jezičnim izrazom.

Za razliku od indirektnih metafora LJUBAVI, koje prevladavaju u tekstu, direktnih je metafora znatno manje, no one su značenjski specifičnije, odnosno bogatije, i složenije na sintaktičkoj razini, što ih čini i funkcionalno važnima za diskurs; kao što primjećuje Aletta Dorst, s čijim je korpusnim istraživanjem i naš rezultat u skladu, naime - „složene je poredbe teško propustiti ili zaboraviti” (219). LJUBAV postaje TIJELOM i uspoređuje se s BOLEŠĆU. Potonje se kao izvorna domena koristi primarno za razumijevanje i izražavanje emocija koje se smatraju negativnima; ti koncepti uključuju i LJUBAV (Kövecses, Metaphor and Emotion 38).

23) Может быть, это жила в нем отвлеченная любовь молодости, превратившаяся в часть тела, ${ }^{[6]}$ либо продолжающаяся сила рождения.

Možda je to u njemu živjela apstraktna ljubav mladosti koja se pretvarala u dio tijela ili snaga rođenja što je trajala i dalje. (Platonov 151)

24) Все было заранее благоустроено: любовь идет в виде факта, в виде определенного, ограниченного вещества, чтобы ей возможно было свершиться и закончиться.

Sve je bilo ranije uređeno: ljubav dolazi u obliku činjenice, u obliku određenih ograničenih tvari kako bi se mogla dogoditi i završiti. (Platonov 357)

DP: u vidu određene, ograničene tvari 
25) Сербинов отказывал любви не только в идее, но даже в чувстве, он считал любовь одним округленным телом, об ней даже думать нельзя, потому что тело любимого человека создано для забвения дум и чувств, для безмолвного труда любви и смертельного утомления;

Serbinov je odbijao ljubav, ne samo u ideji, nego čak i u osjećaju, smatrao je ljubav samo zaobljenim tijelom, o njoj se čak ne smije ni misliti, zato što je tijelo voljenog čovjeka stvoreno da bi se zaboravila kuća ${ }^{7]}$ i osjećaji, za nijem, ljubavni rad i smrtni umor; umor i je jedina utjeha u ljubavi. (Platonov 357)

26) Прокофий их пробовал во время путешествия сжимать, забирая в фаэтон для испытания, но они кричали от его любви, как от своей болезни.

Prokofij in je probao stezati za vrijeme puta, uzimajući in u kočiju radi probe, ali od njegove ljubavi one su vikale, kao od vlastite bolesti. (Platonov 384)

Budući da Schmidt pri određivanju metaforičkih izraza polazi od Lakoff-Johnsonove teorije konceptualne metafore, a ne MIPVU metode Steena i sur., njegova tipologija ne razmatra slučajeve direktnih metafora - između ostalog, onoga što bi klasična tropologija nazvala poredbom. Svi su prijevodi direktnih metafora iznimno bliski originalu, uključujući i zadržavanje signala takvog tipa metafora. Do odstupanja dolazi tek u primjeru 24 u vidu izmjene gramatičkog broja u prijevodu imenice genitiva jednine вещества „tvari” u množinu. Razlog za takvu izmjenu nije moguće pronaći u faktoru konvencionalnosti izraza u hrvatskom jeziku jer odnos analogije između LJUBAVI i TVARI jednako je neuobičajen kao i u ruskom jeziku. ${ }^{[8]}$ Iz prikazanog stoga nije problem zaključiti da prijevodi odražavaju postupak M M. Javlja se pitanje možemo li ih svrstati pod jedan od podtipova toga postupka i koji. Smatramo da ono što Schmidt definira kao prevođenje istim jezičnim izrazom odgovara i slučaju direktnih metafora. Sve dok je odabir metode određivanja metafora jasno naznačen, i dok je u prijevodu ostvareno poklapanje kako na konceptualnoj tako i na jezičnoj razini, podtip ostaje adekvatan. Promjena gramatičkog broja donekle usložnjava kategorizaciju, ali na temelju analize koja se ograničava na rečenicu ne primjećujemo dostatne razlike za svrstavanje u podtip $1 \mathrm{~b}$. 
Kada promotrimo uporabu metafora na razini teksta, primjećujemo da su uporabe jedinice вещества „tvari” pod brojevima 13 і 24, te uporaba jedinice тела/-oм „tijela/-om” primjer dva ponavljanja, tipa uzorka uporabe metafore koji Semino smatra usko povezanim s temom teksta i korisnim u postizanju njegove unutarnje koherentnosti (23). Drugi tip uzoraka uporabe metafora u tekstu jest ekstenzija, odnosno zgusnuto korištenje različitih jedinica koje pripadaju istoj izvornoj domeni za istu ciljnu domenu. Već spomenuta jedinica лежала „ležala”, koja i samostalno funkcionira kao metafora, upravo kroz svoju ekstenziju ljubav podrobnije karakterizira kao živo biće, prizivajući prizor ptice u gnijezdu.

Не одна любовь к срубленной Розе существовала в сердце Копенкина - она лишь лежала в своем теплом гнезде... (21)

U njegovom srcu nije postojala samo ljubav prema pogubljenoj Rosi - ona je samo ležala u svom toplom gnijezdu... (Platonov 130)

U tekstu nalazimo i jedan slučaj tzv. klastera, odnosno zgusnute uporabe metafora koje pripadaju različitim izvornim domenama.

27) Под луной, как под потухшим солнцем, шуршали женщины и девушки - бесприютная любовь людей. Все было заранее благоустроено: любовь идет в виде фракта, в виде определенного, ограниченного вещества, чтобы ей возможно было свершиться и закончиться. Сербинов отказывал любви не только в идее, но даже в чувстве, он считал любовь одним округленным телом, об ней даже думать нельзя, потому что тело любимого человека создано для забвения дум и чувств, для безмолвного труда любви и смертельного утомления; утомление и есть единственное утешение в любви.

Ispod mjeseca, kao ispod ugašenog sunca, šuškale su žene i djevojke - beskućna ljubav muškaraca. Sve je bilo ranije uređeno: ljubav dolazi u obliku činjenice, u obliku određenih ograničenih tvari kako bi se mogla dogoditi i završiti. Serbinov je odbijao ljubav, ne samo u ideji, nego čak i u osjećaju, smatrao je ljubav samo zaobljenim tijelom, o njoj se čak ne smije ni misliti, zato što je tijelo voljenog čovjeka stvoreno da bi se zaboravila kuća i osjećaji, za nijem, ljubavni rad i smrtni umor; umor i je jedina utjeha u ljubavi. (Platonov 357) 
Klasteri su, kao što Semino ističe, funkcionalno vrlo važni dijelovi teksta u kojima se nerijetko ostvaruje ono što je centralno za konačni cilj (govornika, odnosno autora) (24-25). U danom klasteru prepoznajemo ono što bismo mogli uopćiti kao izvorne domene ŽIVO BIĆE, (S)TVAR i TIJELO. Svi se ostvaruju i u prijevodu, popraćeni istim jezičnim izrazima.

Od 102 rezultata pretrage leme любить „Voljeti” pronađene su tek dvije metaforičke uporabe, u tom je smislu glagol znatno manje produktivan od analizirane imenice.

28) Он так больно и ревниво любил паровозы, что с ужасом глядел, когда они едут.

S takvim je bolom i ljubomorom volio lokomotive da je sa strepnjom promatrao kako voze.

(Platonov 18)

DP: bolno

29) Александр Дванов не слишком глубоко любил себя, чтобы добиваться для своей личной жизни коммунизма, но он шел вперед со всеми, потому что все шли и страшно было остаться одному...

Aleksandar Dvanov nije toliko volio sebe da bi za svoj vlastiti život tražio komunizam, on je išao naprijed za svima zato što su svi išli, a njemu je bilo strašno ostati sam... (Platonov 317)

DP: duboko

U primjeru 28 očigledno je riječ o prijevodu iste konceptualne metafore LJUBAV JE BOL istim jezičnim izrazom. Izbjegavanje priloga u prijevodu vjerojatno je prije posljedica težnje za elegantnijem rješenjem nego ograničenja hrvatskog jezika. Zanimljiv je odabir muškog roda imenice bol, čime je se svrstava u fizičku domenu, ${ }^{[9]}$ što svakako nije neobično za temelje konceptualne metafore, s obzirom na čestu konkretnost i utjelovljenost izvorne domene, ali nejasno je koliko je ova odluka pri prijevodu bila namjerna ili utemeljena u dijelovima teksta koji su ostali van granica naše analize. U primjeru 29 vidimo prevođenje konceptualne metafore nemetaforičkom parafrazom. Premda se u originalu radi o naizgled sasvim konvecionalnoj konkretizaciji u vidu prizivanja vrlo česte sheme SPREMNIKA, u širem kontekstu Platonovljeve konceptualizacije LJUBAVI s naglašenim elementima fizičkog, ovdje bi opcija prijevoda M M istim 
jezičnim izrazom „nije tako duboko volio sebe” bila optimalniji izbor od prisutne nemetaforičke parafraze.

\section{Zaključak}

Cijeli je roman smjesa teorije i prakse na način da se idealizirana teorija smješta u konkretni „realni” okvir - pa tako i ljubav. Andrej Platonov, za čija je djela u svojem poznatom predgovoru ovom romanu losif Brodskij rekao da su neprevodiva („Послесловие к 'Котловану' А. Платонова”), svojim posebnim jezikom koji vrlo često uključuje „deformiranje” uobičajenog jezika (na podlozi deformiranja koje je sovjetska ideologija agresivno provodila nad ruskim jezikom) predstavlja poseban problem za prevoditelje. Dakle, Platonov se „ne služi 'prirodnim' jezikom koji bi u ovom slučaju bio jezik 'posrednik', tj. jezik koji govori 'o nečemu', već se on služi jezikom svojstvenim takvom stanju svijesti i društva, deformiranim socijalističkim sovjetskim jezikom deformiranoga socijalističkog sovjetskog društva koji onima koji nisu živjeli u tom društvu zapravo dijelom uvijek ostaje tuđ” (Božić, Distopija i jezik 31). Jedan od mogućih alata pri prevođenju, ali i pri „kontroli” prijevoda jest i korpusna analiza tako složenog prijevodnog problema kao što je konceptualna metafora.

U ovom radu analizirani su primjeri prijevoda koji se odnose na LJUBAV kao ciljnu domenu metafore. Istraživanje postupaka prijevoda konceptualnih metafora LJUBAVI pokazuje da u prijevodu prevladava postupak M M, odnosno prevođenje istom konceptualnom metaforom, unutar kojeg pak očito prevladava prevođenje istim jezičnim izrazom. Nekoliko se iznimaka može objasniti različitim konvencijama hrvatskog jezika u odnosu na ruski, dok, naravno, određene motivacije prevoditelja neminovno ostaju izvan istraživačkih okvira. Primijećena dominantnost navedenog postupka nije začudna ako uzmemo u obzir mogućnosti izvornog i ciljnog jezika - slavensko kulturno i jezično nasljeđe koje, barem u određenoj mjeri, omogućuje razumijevanje dijeljenih koncepata i uporabu istih jezičnih izraza. Daljnja istraživanja rusko-hrvatskih prijevoda književnoumjetničkih tekstova mogu pomoći otkriti granice zajedničkoga.

Nadalje, pokazali smo potencijal korpusne provjere u onim slučajevima kada rječnici kao kontrolni korpus dosegnu svoja ograničenja i kada intuicija prevoditelja ne može razriješiti pitanja nijansi odstupanja od uobičajene uporabe metaforičkih izraza. Dokazali smo i mogućnosti alata pri provjeri 
prijevoda, tj. „prepoznavanju” nemetaforičke uporabe ondje gdje je prevoditelj pretpostavio metaforičku, ali i obratno.

Premda će konačna odluka u svakom slučaju pasti na prevoditelja, korpusni su alati, ali i nove spoznaje teorije konceptualne metafore, vrijedna pomoć čije se integriranje u istraživanje prijevoda i u sam proces prevođenja metafora čini sve važnijim.

\section{Works Cited}

Božić, Rafaela. Distopija i jezik: distopijski roman kroz oko lingvostilistike. Sveučilište u Zadru, 2013.

Božić, Rafaela. „On Translating Metaphors. Problems of Research Methodology.” Croatica et Slavica ladertina, vol. 14/1, br. 14, 2018, str. 87-99. Hrčak, hrcak.srce.hr/218445. Pristupljeno 6. veljače 2021.

Brodskij, losif. „Послесловие к 'Котловану' А. Платонова” [„Posleslovie k 'Kotlovanu' A. Platonova"]. Lib.Ru: Библиотека Максима Мошкова [Lib.Ru: Biblioteka Maksima Moshkova], lib.ru/BRODSKIJ/br_platonov.txt. Pristupljeno 12. lipnja 2020.

Deignan, Alice. Metaphor and Corpus Linguistics. John Benjamins Publishing Company, 2005.

Dobrzynska, Teresa. „Translating Metaphor: Problems of Meaning.” Journal of Pragmatics, vol. 24, br. 6, 1995, str. 595-604.

Dorst, Aletta G. Metaphor in Fiction: Language, Thought and Communication. 2011. Vrije Universiteit, Doktorska disertacija.

Jensen, Astrid. „Coping with Metaphor: A cognitive approach to translating metaphor.” Hermes, J ournal of Linguistics, vol. 35, br. 18, 2005, str. 185-207. Researchgate, www.researchgate.net/publication/314386154_Coping_with_Metaphor_A_cognitive_approach_to_translating_m Pristupljeno 12. srpnja 2020.

Kalyuga, Marika. Russian Prepositional Phrases. A Cognitive Linguistic Approach. Springer Publishing, 2020. Springer Link, www.springer.com/gp/book/9789811552151. 
Kövecses, Zoltán. Metaphor and Emotion: Language, Culture, and Body in Human Feeling. Cambridge University Press, 2003.

Kövecses, Zoltán. Metaphor: A Practical Introduction. 2. izd., Oxford University Press, 2010.

Kövecses, Zoltán. Metaphors of Anger, Pride and Love. A Lexical Approach to the Structure of Concepts. John Benjamins Publishing Company, 1986.

Kövecses, Zoltán. „The Scope of Metaphor.” Metaphor and Metonymy at the Crossroads: A Cognitive Perspective, uredio Antonio Barcelona, Mouton de Gruyter, 2003, str. 79-92.

Lakoff, George i Mark Johnson. Metaphors We Live By. University of Chicago Press, 1980.

Matovac, Darko. Semantika hrvatskih prijedloga. 2013. Sveučilište Josipa Jurja Strossmayera, Doktorska disertacija.

Platonov, Andrej. Čevengur. Prevela Rafaela Božić Šejić, Breza, 2005.

Schäffner, Christina. „Metaphor and translation: some implications of a cognitive approach.” Journal of Pragmatics, vol. 36, br. 7, 2004, str. 1253-1269.

Schmidt, Goran. „Konceptualne metafore u prevođenju.” Metafore koje istražujemo: suvremeni uvidi u konceptualnu metaforu, uredio Mateusz-Milan Stanojević, Srednja Europa, 2014, str. $117-143$.

Semino, Elena. Metaphor in Dicourse. Cambridge University Press, 2008.

Steen, Gerard, et al. A Method for Linguistic Metaphor Identification: From MIP to MIPVU. John Benjamins Publishing Company, 2010.

Ušakova, Natalia I. „Cognitive-Activity Bases for Translational Interpretation of a Foreign Language Text." Cross-Cultural Studies: Education and Science, vol. 5, br. 3, 2020, str. 80-88.

Hrvatski jezični portal. 2006-2020, hjp.znanje.hr/index.php?show=main. Pristupljeno 27. rujna 2020.

Školski rječnik hrvatskoga jezika. rjecnik.hr/search/?q=bol. Pristupljeno 27. rujna 2020.

Национальный корпус русского языка [Nacional'nyj korpus russkogo jazyka]. 2003-2020, www.ruscorpora.ru/. Pristupljeno 20. rujna 2020. 
Толковый словарь Ожегова [Tolkovyj slovar' Ozhegova]. 2005-2020, gufo.me/dict/ozhegov.

Pristupljeno 20. rujna 2020. 
[1] Potencijalni slučajevi prijevoda u vidu dodavanja navedene imenice i glagola ondje gdje u originalu izostaju time su isključeni.

[2] Oznaka DP stoji za „doslovan prijevod”; navodimo ga samo ondje gdje se analizirani prijevod razlikuje od originala i to samo za istaknutu leksičku jedinicu čiju vezu s lemom istražujemo.

[3] Ruski je prijedlog из-за nastao spojem prijedloga из „iz” і prijedloga за „za”. Kalyuga navodi kako prostorno značenje konstrukcije из-за+GEN označava točku izvora koja se nalazi iza orijentira (en. landmark) (50); konceptualiziranjem UZROKA pomoću izvorne (prostorne) domene IZVORA konstrukcija označava uzrok s neželjenim ishodom (Kalyuga 66). U hrvatskom je jeziku prijedlog iza također izveden iz prijedloga iz i za, međutim, kako ističe Matovac, „značenje [je] ablativnosti potisnuto te je prevladalo značenje smještenosti” (256). Time je i metafora UZROKA izgubljena i iza se koristi samo u doslovnom, prostornom značenju, dok je jednostavni prijedlog iz zadržao i prostorno i ne-prostorno, odnosno uzročno značenje.

[4] Gramatički pravilan prijevod ovdje bi bio: Zato što prirodu poštujemo zbog hrane, a žene zbog ljubavi. Prijevodno rješenje bilo je vjerojatno pod utjecajem stalne tehnike oneobičenja prisutne u romanu - ovo je odličan primjer da je korištenje korpusa moglo prevoditeljici pomoći da prepozna neutralno mjesto i prevede ga očekivanom konstrukcijom.

[5] Točnije, pri pretraživanju imenice вещество deset mjesta udesno našli smo sljedeći primjer: „Если бы человьческія страсти и чувства, симпатіи и антипатіи, любовь и ненависть были подобны взрывчатымъ веществамъ, или положительному и отрицательному электричеству маленькій домикъ, стоявшій на rue de la Gare должно было бы взорвать и разнести на мелкія части" (Национальный корпус русского языка). On je odbačen zbog atribucije pomoću pridjeva взрывчатый „eksplozivan”, koja konstrukciju značenjski odvaja od samostalne jedinice вещество.

[6] lako glagol превратиться „pretvoriti se” nije tipičan primjer signaliziranja direktnih metafora, smatramo da uspostavlja vezu između odvojenih domena LJUBAVI i TIJELA, pri čemu je semantički relevantan dio toga odnosa upravo часть тела „dio tijela”, a ne sam glagol, koji nije upotrijebljen metaforički. Stoga smo odlučili primjer ipak označiti kao metaforu, ali direktnog tipa. Unatoč sintaktičkoj složenosti, primjer promatramo kao jednu direktnu metaforu; isto vrijedi i za primjere 24, 25, 26. 
[7] Ovdje se u prijevodu otkriva greška - umjesto дум „misli”, prevodi se kuća - omaškom od дом.

[8] Kao što pokazuje pretraga na Googleu, 27. 9. 2020.

[9] Naime, normativna je preporuka suvremenog hrvatskog jezika korištenje muškog roda imenice bolovi u značenju tjelesne patnje, a ženske boli kada se radi o duhovnoj patnji, kao što pokazuju elektronička izdanja rječnika - Hrvatski jezični portal i Školski rječnik hrvatskoga jezika.

\section{(c) (i) (3)}

Creative Commons Attribution-NonCommercial-NoDerivatives 4.0 International License 